\title{
Fluorescence of cyanine dye excimers in nanoporous silica
}

\author{
A.V.Sorokin, B.A.Gnap, I.I.Bespalova, S.L.Yefimova \\ Institute for Scintillation Materials, STC "Institute for Single Crystals", National \\ Academy of Sciences of Ukraine, 60 Lenin Ave., 61001 Kharkiv, Ukraine
}

Received May 24, 2015

\begin{abstract}
Adsorption of cyanine dye $\mathrm{Dil}$ in a nanopous $\mathrm{SiO}_{2}$ matrix has been studied. It was shown that the increase of the dye concentration in the $\mathrm{SiO}_{2}$ matrix provokes the appearance of an additional red-shifted band of excimer nature in the dye fluorescence spectrum without any changes in the absorption one. Static character of the dye excimer formation was revealed. Enhanced dye concentration due to spatial confinement in a nanopore volume has been supposed as a reason of the effective excimer formation.

Keywords: cyanine dye, nanoporous silica, excimer, fluorescence.
\end{abstract}

\begin{abstract}
Исследована адсорбция цианинового красителя Dil в нанопористой $\mathrm{SiO}_{2}$ матрице. Увеличение концентрации красителя приводит к появлению новой полосы в спектре флуоресценции, смещенной в длинноволновую область, которое не сопровождается трансформацией спектра поглощения. Показана эксимерная природа длинноволновой полосы флуоресценции. Обнаружен статический характер образования эксимеров красителя. В качестве причины әффективного образования эксимеров предположено принудительное концентрирование красителя из-за пространственного ограничения в объеме нанопор.
\end{abstract}

Флуоресценція ексимерів ціанінового барвнику у нанопористому оксиді кремнію. О.В.Сорокін, Б.А.Гнап, І.І.Беспалова, С.Л.Єфімова

Досліджено адсорбцію ціанінового барвнику Dil у нанопористій $\mathrm{SiO}_{2}$ матриці. Збільшення концентрації барвнику призводить до появи нової смуги у спектрі флуоресценції, що зміщена у довгохвильову область, яка не супроводжується трансформацією спектра поглинання. Показано ексимерну природу довгохвильової смуги флуоресценції. Виявлено статичний характер формування ексимерів барвнику. В якості причини ефективного формування ексимерів припущено примусове концентрування барвнику внаслідок просторового обмеження в об’ємі нанопір.

\section{Introduction}

Nanoporous materials are very attractive due to their ability to adsorb atoms, ions and molecules on their large interior surfaces and in the nanometer sized pore space $[1,2]$. Particularly, they could be used as a host for fluorescent molecules providing them novel properties, for example, enhanced photostability [3], supramolecular organization, etc. $[4,5]$. Nanoporous $\mathrm{SiO}_{2}$ matrices are very promising hosts for organic and inorganic molecules via their quite gentle synthetic conditions, rigidity and transparent glass formation [4, 6-9].

Recently, we have reported an excimer formation of a cyanine dye $\mathrm{DiD}$ in a $\mathrm{SiO}_{2}$ matrix [10]. The excimers are dimers composed of molecules one of which is in excited state [11]. The excimer formation in the nanoporous silica is well studied process for pyrene [8, 12-16], naphthalene [17] and some other polyaromatic hydrocarbons [18] which arises from their liability to excimerization in solutions [11]. Contrary to 

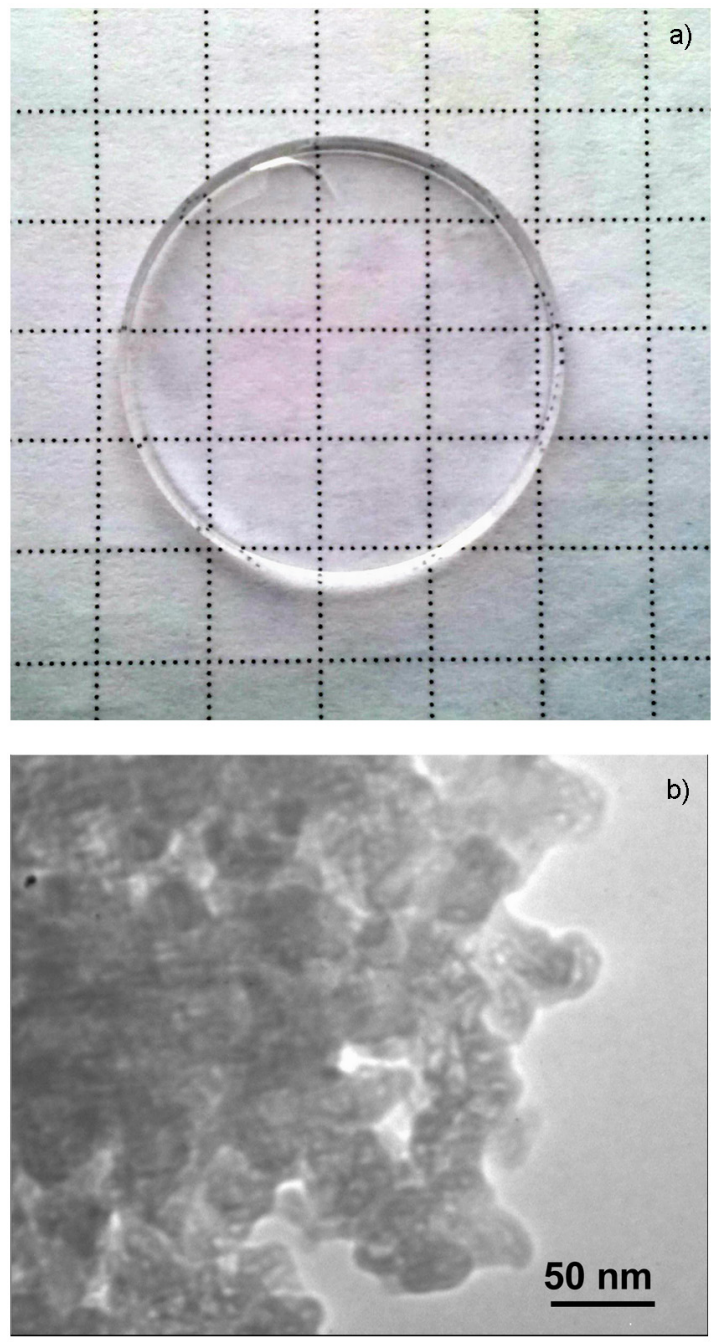

Fig. 1. Photographic (a) and TEM (b) images of $\mathrm{SiO}_{2}$ matrix.

the polyaromatic hydrocarbons, the excimer formation for cyanines has not been observed previously for the best of our knowledge. So, photophysics and peculiarities of the cyanines excimerization should to be studied carefully.

In the present paper, we report features of the excimer fluorescence of another cyanine dye Dil adsorbed in $\mathrm{SiO}_{2}$ matrices.

\section{Experimental}

Transparent $\mathrm{SiO}_{2}$ sol-gel round plates with $\sim 2 \mathrm{~cm}$ diameter and $1 \mathrm{~mm}$ thickness (Fig. 1a) were synthesized by the methods described elsewhere [19]. After polycondensation finishing matrices was annealed at $750^{\circ} \mathrm{C}$. To work with the same matrix within experiment series, each matrix was divided in several pieces. Dil $\left(1,1^{\prime}\right.$-dioctadecyl-3,3,3', 3'-tetramethylindocarbocyani

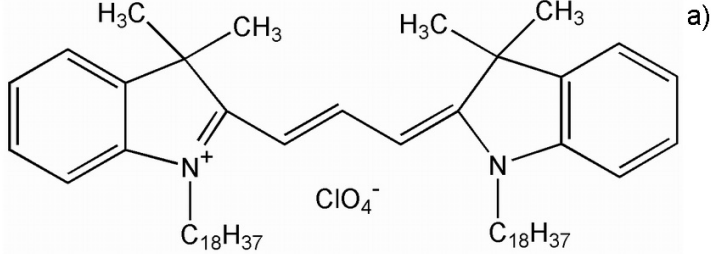

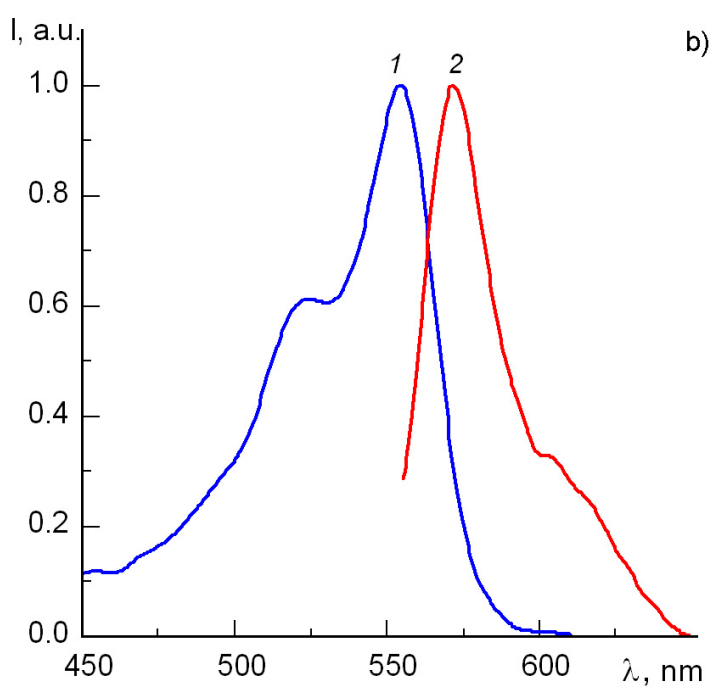

Fig. 2. Structural formula of Dil dye (a) and absorption (1) and fluorescence $\left(2, \lambda_{\text {exc }}=\right.$ $530 \mathrm{~nm}$ ) spectra of the dye in $\operatorname{DMF}(\mathrm{b})$.

ne perchlorate, Fig. 2a) dye was obtained from Sigma-Aldrich (USA) and used as received. To embed dyes into $\mathrm{SiO}_{2}$ matrix its pieces were placed into the dye chloroform solution for at least one hour. After that samples were dried at temperature $60^{\circ} \mathrm{C}$ for at least three hours.

Luminescence and luminescence excitation spectra were recorded using fluorescence spectrometer Lumina (Thermo Scientific, USA) equipped with solid sample holder. For luminescence measurement $\lambda_{\text {exc }}$ $=530 \mathrm{~nm}$ has been used. Absorption spectra was registered using a microspectrometer USB4000 (Ocean Optics, USA) supplied with an incandescent lamp. Luminescence decay spectra were registered using FluoTime 200 fluorescence lifetime spectrometer (PicoQuant, Germany) equipped with $531 \mathrm{~nm}$ picosecond pulsed laser diode head. An instrument response function (IRF) full width at half maximum ( $\triangle F W H M)$ for the whole setup was about 100 ps. Decay time analysis has been performed using FluoFit software (PicoQuant, Germany). The porosity of silica matrices has been measured by Physisorption Analyzer ASAP 2000 (Micromeritics, USA) using nitrogen as an analysis gas. 


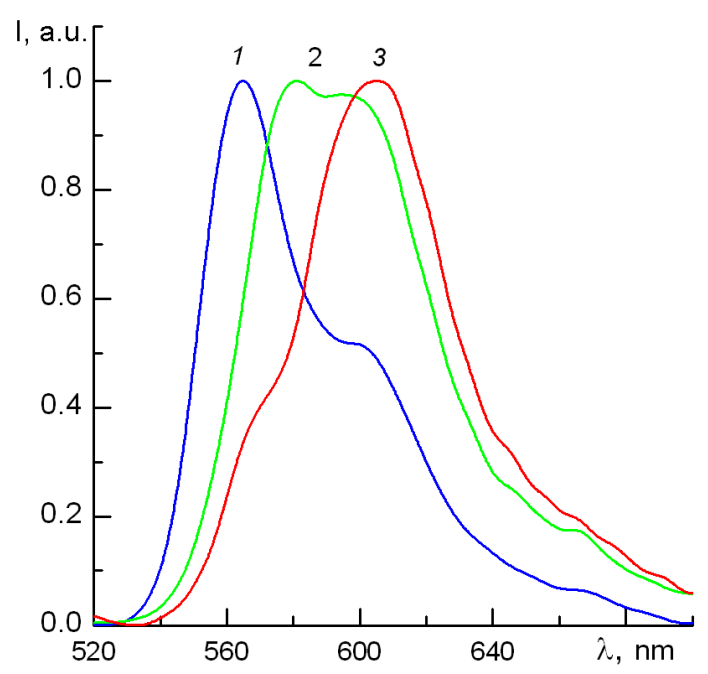

Fig. 3. Fluorescence spectra $\left(\lambda_{\text {exc }}=530 \mathrm{~nm}\right)$ of Dil in the silica matrices depending on the dye concentration in chloroform solutions: $1-C-10^{-6} \mathrm{M}, 2-C=10^{-5} \mathrm{M}$ and $3-C=10^{-4} \mathrm{M}$.

\section{Results and discussion}

The analysis of the literature data shows that there is a string dependence of the polyaromatic hydrocarbons excimerization efficiency on the pore size [13-16]. Indeed, the pore size decrease from several tens nanometers down to approximately 3-4 $\mathrm{nm}$ leads to the increase of the excimer fluorescence [13-15]. However, further decreasing pore size causes the decrease in excimerization efficiency as a result of spatial confinement preventing the dye molecule diffusion in pores to form excimers [16].

So, first of all we should clarify the structure of obtained silica matrices. Studying the matrices surface by atomic force microscopy (AFM) revealed open pores with the diameters about $10-20 \mathrm{~nm}$ [9]. But pores located in a matrix volume should be much smaller as compared with the surface ones [7, 8]. TEM images of the matrix edge reveal that the matrix consists of silica nanoparticles with average size of about $30 \mathrm{~nm}$ (Fig. 1a). Some of pores between them are quit large and correlated with the size of the surface pores. But others are smaller and couldn't be resolved by TEM. To estimate their size the gas sorption technique has been used. It reveals the average pore diameter about $21 \AA$ with average micropore volume of $0.2 \mathrm{~cm}^{3} / \mathrm{g}$ and average pore area of $390 \mathrm{~m}^{2} / \mathrm{g}$. Taking into account the Dil molecule size about $14 \AA$ (Fig. 2a) we could conclude a possibility of the dimer formation in the silica pores. Another fac-

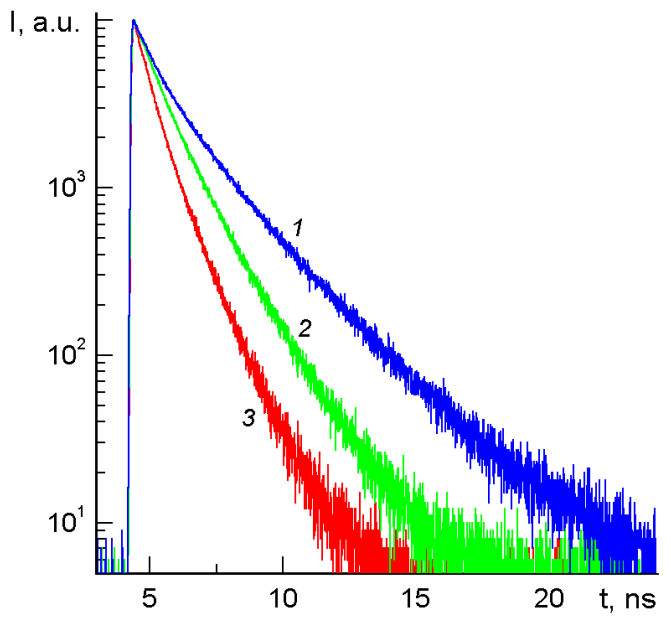

Fig. 4. Fluorescence decay curves $\left(\lambda_{\text {exc }}=\right.$ $531 \mathrm{~nm}$ ) of Dil in the silica matrices depending on the dye concentration in chloroform solutions and registration wavelength:

$$
\begin{aligned}
& 1-C=10^{-6} \mathrm{M}, \lambda_{\text {reg }}=565 \mathrm{~nm} ; \\
& 2-C=5 \cdot 10^{-5} \mathrm{M}, \lambda_{\text {reg }}=600 \mathrm{~nm} ; \\
& 3-C=10^{-4} \mathrm{M}, \lambda_{\text {reg }}=605 \mathrm{~nm} .
\end{aligned}
$$

tor to be considered is a restricted geometry or fractal geometry of the pore volume that results in non-uniform dye distribution in the matrices leading to facilitated excimer formation [15, 20]. Indeed, studying features of non-radiating energy transfer between two dyes incorporated into the silica matrix shown it apparent fractal dimensionality $d=2.74[21]$.

In proper solvents such as alcohols, DMF, chloroform and some others Dil dye presents in monomeric form with high extinction coefficient $\left(\lambda_{\text {max }}{ }^{a b s}=550 \mathrm{~nm}\right.$, $\varepsilon=148000 \mathrm{M}^{-1} \cdot \mathrm{cm}^{-1}$ in $\mathrm{MeOH}$ ) and modest fluorescence $\left(\lambda_{\max }{ }^{\text {fluo }}=575 \mathrm{~nm}\right.$, quantum yield is about 0.07 in $\mathrm{MeOH}$ ) (Fig. 2b). To embed the dye into the silica matrix it pieces were immersed in a chloroform dye solution with a different dye concentrations (from $10^{-6} \mathrm{M}$ to $10^{-4} \mathrm{M}$ ). The dye loading efficiency was about $3 \%$ by weight that is similar to that reported in $[9,10]$.

At small Dil concentration $\left(C=10^{-6} \mathrm{M}\right)$ the colored matrix reveals absorption (not shown $)$ and fluorescence $\left(\lambda_{\max }{ }^{\text {mon }}=\right.$ $565 \mathrm{~nm}$ ) bands of Dil monomers (Fig. 3, curve 1) slightly shifted to the long-wavelength side as compared to the spectra in the solution (Fig. 2b) due to the solvatochromic effect [9, 10]. The fluorescence band hereafter will be referred as monomeric one. Using the more concen- 
trated solution for the matrix impregnation results in novel red-shifted band appearance in the fluorescence spectrum with $\lambda_{\max }$ exc $=$ $605 \mathrm{~nm}$ (Fig. 3). With the increase of the dye concentration, a redistribution of the both band intensities is observed: the redshifted band becomes the most intense, while the monomeric one transforms into a shoulder (Fig. 3, curve 3). It should be noted that in increase in the dye concentration do not provokes any changes in the absorption band (not shown) that is similar to the case of DiD dye reported earlier [10]. Such concentration dependent red-shifted fluorescence band and concentration independent absorption one are characteristic features of excimer formation [11].

To prove this conclusion, the fluorescence decays have been studied in dependence on the dye concentration in the solution and the fluorescence band maximum position (Fig. 4). One could observe remarkable shortening the fluorescence decay time with the dye concentration growing. Fluorescence decay registered in the monomeric band maximum has an average lifetime $\tau^{m o n} \sim 1.34 \mathrm{~ns}$ (with mutiexponential character of decay curve), while the red-shifted fluorescnce has an average lifetime $\tau^{e x c} \sim 0.63 \mathrm{~ns}$. Such the lifetime shortening is agreed with the data obtained for DiD dye [10] and in accordance with excimeric nature of the emission [11]. Contrary to typical pyrene excimer fluorescence decay features $[8,15,16]$, we could not observe a growing-in time of the excimer formation due to the molecule diffusion (Fig. 4).

It could be a feature of so-called groundstate or "static" excimer formation [15, 22]. In this case, two molecules are placed in close proximity but they do not form a dimer due to unfavorable arrangement. When one of the molecules is excited a very quick rearrangement occurs leading to the excimer formation. To prove that situation, the fluorescence excitation spectra were recorded with registration in the monomeric and excimeric band maxima (Fig. 5). The monomeric fluorescence excitation spectrum with $\lambda_{\max }=548 \mathrm{~nm}$ (Fig. 5) coincides with the dye absorption spectrum (Fig. 2b), while the excimeric fluorescence excitation spectrum reveals two additional bands one of each is blue-shifted $\left(\lambda_{\max }\right.$ blue $\left.=475 \mathrm{~nm}\right)$ and another one is red-shifted $\left(\lambda_{\max }\right)^{\text {red }}=$ $568 \mathrm{~nm}$ ) related to the monomeric band (Fig. 5). The band splitting corresponds to dimer formation [23] in excited state and

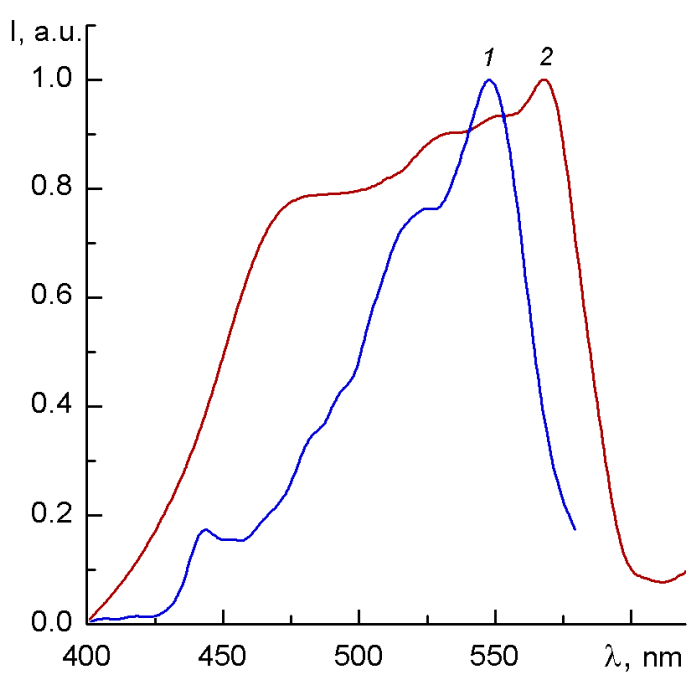

Fig. 5. Fluorescence excitation spectra of Dil monomeric band $\left(1, \lambda_{\text {reg }}=590 \mathrm{~nm}, C=10^{-6} \mathrm{M}\right.$ in chloroform solution) and excimer band $\left(2, \lambda_{\text {reg }}=630 \mathrm{~nm}, C=10^{-4} \mathrm{M}\right.$ in chloroform solution).

confirms the static nature of the Dil excimers formed in the nanopous silica matrix $[15,22]$.

\section{Conclusions}

Cyanine dye Dil has revealed an effective excimer formation in porous silica matrix with average pore diameter of $21 \AA$. The excimer fluorescence band is $40 \mathrm{~nm}$ shifted to the longer wavelengths relative to the monomeric band and reveals about two times shorter lifetime. The monomeric band splitting in the fluorescence excitation spectrum of the excimer band indicates the static nature of the dye excimer formation. It could be assigned to a forced concentration of the molecules in the small volume of nanopores.

Acknowledgements. Authors are grateful to Prof.A.V.Ragulya (V.Lashkaryov Institute of Semiconductor Physics of NAS of Ukraine) for the help with porosity measurements and Dr.S.I.Bogatyrenko (V.Karazin Kharkiv National University) for the help with Transmission Electron Microscopy imaging.

\section{References}

1. G.Q.Lu, X.S.Zhao (Eds.), Nanoporous Materials: Science and Engineering, Imperial College Press, London, 900 (2004).

2. S.Ernst (Ed.), Advances in Nanoporous Materials, Elsevier, Oxford, 312 (2009).

3. A.Dubois et al., Appl. Opt., 35, 3193 (1996). 
4. R.Reisfeld, J. Fluorescence, 12, 317 (2002).

5. G.Calzaferri et al., J.Mater.Chem., 12, 1 (2002).

6. O.N.Bezkrovnaya et al., J.Non-Crystal. Solids, 389, 11 (2014).

7. J.D.Wright, N.A.J.M.Sommerdijk, Sol-Gel Materials: Chemistry and Applications, Taylor \& Francis, London, 125 (2001).

8. J.K.Thomas, E.H.Ellison, Adv.Coll.Interf. Sci., 195, 89 (2001).

9. B.A.Gnap et al., Functional Materials, 18, 487 (2011).

10. B.A.Gnap et al., Functional Materials, 20, 407 (2013).

11. J.B.Birks, Rep. Prog. Phys., 38, 903 (1975).

12. K.A.Zachariasse in Photochemistry on Solid Surfaces ed. by M.Anpo, T.Matsuura, Elsevier, Amsterdam, Oxford, New York, Tokyo, 48 (1989).
13. T.Fujii et al., J.Photochem.Photobiol.A, 86, 219 (1995).

14. R.Dabestani et al., J.Phys.Chem.C, 112, 11468 (2008).

15. E.Wellner et al., Langmuir, 2, 616 (1986).

16. A.Thomas et al., J.Phys.Chem. B, 107, 5081 (2003).

17. M.E.Sigman et al., New.J.Chem., 20, 243 (1996).

18. J.T.Barbas et al., J.Photochem.Photobiol.A, 109, 229 (1997).

19. T.A.Blank et al., Functional Materials, 16, 517 (2009).

20. J.M.Drake, J.Klafter, J.Luminescence, 642, 31(1984).

21. S.L.Yefimova et al., Appl.Phys.A, 116, 2131 (2014).

22. T.Fujii, E.Shimizu, Chem.Phys.Lett., 137, 448 (1987).

23. W.West, S.Pearce, J.Phys.Chem., 69, 1894 (1965). 